\title{
Calcium-Dependent Secretion Activator 2
}

National Cancer Institute

\section{Source}

National Cancer Institute. Calcium-Dependent Secretion Activator 2. NCI Thesaurus.

Code C158577.

Calcium-dependent secretion activator 2 (1296 aa, $148 \mathrm{kDa}$ ) is encoded by the human CADPS2 gene. This protein is involved in the secretion of neurotrophins. 